\title{
Pengaruh Pandemik Covid-19 Terhadap Pendapatan Tempat Wisata dan Kinerja Karyawan Pariwisata di Jakarta
}

\author{
Soehardi ${ }^{1, *}$, Diah Ayu Permatasari ${ }^{2}$, Janfry Sihite ${ }^{3}$ \\ ${ }^{1}$ Fakultas Ekonomi dan Bisnis; Universitas Bhayangkara Jakarta Raya; Jl. Harsono RM No 67 \\ Ragunan Pasar Minggu Jakarta 12140, +622188955882/+622188955871; e-mail: \\ soehardi@dsn.ubharajaya.ac.id; \\ ${ }^{2}$ Fakultas IImu Komunikasi; Universitas Bhayangkara Jakarta Raya; Jl. Harsono RM No 67 \\ Ragunan Pasar Minggu Jakarta 12140, +622188955882/+622188955871; e-mail: \\ pepy@ubharajaya.ac.id \\ ${ }^{3}$ Fakultas Ekonomi dan Bisnis; Universitas Mercu Buana; Jl. Meruya Selatan No 1 Kembangan \\ Jakarta Barat 11650, +62215840816/+62215857733; e-mail: janfry.sihite@mercubuana.ac.id \\ * Korespondensi: e-mail: soehardi@dsn.ubharajaya.ac.id
}

\begin{abstract}
This study aims to determine the impact of the co-19 pandemic on the tourism industry, especially tourism and entertainment revenue as well as the performance of tourism employees in Jakarta. The research method used is a quantitative research method with composite reliability analysis, cronbach's alpha, average variance extracted, $t$ test and $r$ square using Partial Least Square (PLS) Structural Equation Model (SEM). The population in this study were all tourism employees in Jakarta using simple random sampling data obtained amounted to 93. There is a significant influence of the covid-19 pandemic on the performance of tourism employees in Jakarta. The longer the covid-19 pandemic, the more influence on the decline in the performance of tourism employees. The most dominant of covid-19 pandemic indicator is the inherent risk of covid-19 transmission compared to other indicators such as massive testing, equipment availability and health protocols. The most dominant of employee performance indicator is task performance by way of work from home and work from office when compared to other indicators such as adaptive performance or contextual performance. Temporary closure of tourist attractions and entertainment has a negative impact on the decline in tourism employee performance such as employee reductions, salary deduction and incentives and layoffs. There is a significant influence of the co-19 pandemic on the revenue of tourist attractions in Jakarta. The longer of covid-19 pendemic, the more influence on income decreases tourist attractions. The most dominant indicator of tourist and entertainment revenue is the amount of original regional revenue from the tourism and entertainment tax sector. There is a significant influence of tourist attraction revenue on the performance of tourism employees in Jakarta. Revenue of tourist attractions decreases, then the effect on the decline in the performance of tourism employees.
\end{abstract}

Keywords: covid-19 pandemic, revenue of tourism places and tourism employee performance

\begin{abstract}
Abstrak
Penelitian ini bertujuan untuk mengetahui dampak pandemik covid-19 pada industri pariwisata, khususnya pendapatan tempat wisata dan hiburan serta kinerja karyawan pariwisata di Jakarta. Metode penelitian yang digunakan adalah metode penelitian kuantitatif dengan analisis composite reliability, cronbach's alpha, average variance extracted, uji t dan $r$ square menggunakan Partial Least Square (PLS) Structural Equation Model (SEM). Populasi dalam
\end{abstract}


penelitian ini adalah seluruh karyawan pariwisata di Jakarta dengan menggunakan simple random sampling diperoleh data berjumlah 93. Pengaruh yang signifikan pandemik pandemik covid-19 terhadap kinerja karyawan pariwsata di Jakarta. Semakin lama pandemik covid-19, maka semakin berpengaruh pada penurunan kinerja karyawan pariwisata. Indikator pandemik covid-19 yang paling dominan adalah resiko inheren penularan covid-19 dibandingkan dengan indikator lainnya seperti massive testing, equipment availability dan protokol kesehatan. Indikator kinerja karyawan yang paling dominan adalah kinerja tugas atau task performance dengan cara work from home and work from office apabila dibandingkan dengan indikator lainnya seperti kinerja adaptif atau adaptive performance and kinerja kontektual atau contextual performance. Penutupan sementara tempat wisata dan hiburan berdampak negatif pada penurunan kinerja karyawan pariwisata seperti pengurangan karyawan, pemotongan gaji dan insentif serta pemutusan hubungan kerja (PHK). Pengaruh pandemik covid-19 terhadap pendapatan tempat wisata di Jakarta. Semakin lama pendemik covid-19, maka semakin berpengaruh pada penurunan pendapatan pendapatan tempat wisata. Indikator pendapatan tempat wisata dan hiburan yang paling dominan adalah jumlah penerimaan asli daerah dari sektor pajak wisata dan hiburan. Pengaruh pendapatan tempat wisata terhadap karyawan pariwsata di Jakarta. Pendapatan tempat wisata semakin menurun, maka berpengaruh pada penurunan kinerja karyawan pariwisata.

Kata kunci: pandemik covid-19, pendapatan tempat wisata dan kinerja karyawan pariwisata.

\section{Pendahuluan}

Menurut (Harahap, 2020), pemerintah China melaporkan kepada PBB tanggal 31 Desember 2019 tentang wabah Corona virus disease (Covid) 19 di Wuhan, Provinsi Hubei, China. Dari Wuhan ini, Covid-19 ini menyebar ke seluruh dunia, termasuk juga Indonesia melalui lalu lintas orang dan barang dengan menggunakan rute penerbangan dan pelayaran internasional.

Pada tanggal 11 Maret 2020, (World Health Organization, 2020) mengumumkan Covid19 sebagai pandemic global. Setelah pengumuman ini, beberapa negara melarang orang asing untuk berkunjung ke negaranya, termasuk pemerintah Indonesia melarang warga negara asing berkunjung ke Indonesia. Pelarangan warga negara asing ini berdampak pada terhentinya rute penerbangan internasional dan berpengaruh pada penurunan wisatawan asing berkunjung ke Jakarta, Indonesia.

Pemerintah Indonesia, Kementerian Kesehatan dan Pemerintah Provinsi mengeluarkan kebijakan Pembatasan Sosial Berskala Besar (PSBB) dengan tujuan untuk pencegahan penularan pandemik covid 19 di masyarakat, sekolah, kampus dan perkantoran baik instansi pemerintah maupun swasta. Kebijakan PSBB ini berdampak pada tidak beroperasi beberapa perusahaan penerbangan wings air, air asia, citilink dan batik air dengan rute penerbangan dan pelayaran internasional maupun domestik pada bulan Maret 2020 hingga pertengahan bulan Juni 2020. Pandemik covid-19 ini mempengaruhi penurunan wisatawan domestik yang berkunjung ke Jakarta.

Pemerintah Provinsi DKI Jakarta melalui (Kepala Dinas Pariwisata dan Ekonomi Kreatif DKI Jakarta, 2020) mengeluarkan Surat Edaran nomor: 155/SE/2020, 160/SE/2020 DAN 184/SE/2020 tentang penutupan sementara kegiatan operasional industry pariwisata, termasuk 
tempat-tempat wisata dan hiburan sejak 20 Maret - 2 April, 20 Maret - 5 April 2020 dan 6 - 19 April 2020. Penutupan sementara ini akan menurunkan pendapatan bisnis tempat wisata dan hiburan sehingga dapat menurunkan pendapatan pajak tempat wisata dan hiburan. Hal tersebut didukung oleh beberapa riset di seluruh dunia dalam memprediksi puncak sebaran COVID-19 yang beberapa negara sudah masuk dalam masa Ionjakan kedua. Untuk wilayah Indonesia beberapa peneliti menggunakan pendekatan soft computing, seperti Support Vector Machine (SVM) regression, dengan beberapa kernel pilihan, antara lain radial basis function, linear and polynomial dengan akurasi yang beragam. Alat bantu dari Google (Google Interactive Notebook) sangat membantu dengan fasilitas kompiler dan servernya (Herlawati, 2020).

Dalam mengatasi wabah COVID-19, pemerintah tidak melakukan karantina wilayah (lock down) tetapi menggunakan kebijakan Pembatasan Sosial Berskala Besar (PSBB). Dimulai dari ibukota Jakarta, kebijakan ini diikuti oleh wilayah lainnya. Kota Bekasi sebagai wilayah penyangga Jakarta segera menerapkan kebijakan PSBB mengingat wilayah ini berdekatan dengan dikhawatirkan terpengaruh dengan kota Jakarta yang merupakan zona merah dengan hampir separuh kasus COVID-19 ada di wilayah Jakarta. Banyak pihak yang mendukung dan juga kurang setuju dengan PSBB, namun agar perekonomian tetap berjalan dan wabah dapat diatasi, pemerintah tidak mengambil kebijakan karantina wilayah. Untuk mengetahui efektifitas PSBB di kota Bekasi, penelitian ini mencoba menggunakan model SusceptibleInfectedRecoverd (SIR) untuk mengukur laju penyebaran COVID-19. Hasilnya menunjukan adanya laju penurunan kasus terinfeksi dengan beta dan gamma beruturut-turut sebesar 0,071 dan 0,05 dan diprediksi akan berakhir di bulan Juni 2020. (Handayanto \& Herlawati, 2020)

Beberapa permasalahan kinerja karyawan tempat wisata dan hiburan dalam masa pandemic covid-19 antara lain: gagap teknologi dalam melakukan kegiatan secara online atau daring, pemakaian masker saat bekerja, cuci tangan dengan sabun, perilaku hidup bersih dan sehat, peningkatan biaya pulsa dan listrik di rumah ketika work from home.

\subsection{Covid 19}

(Keppres, 2020) Keputusan Presiden Nomor 9 Tahun 2020 tentang Gugus Tugas Percepatan Penanganan Corona Virus Disease 2019 (COVID-19), (Pemerintah Republik Indonesia, 2020) Peraturan Pemerintah Nomor 21 Tahun 2020 tentang Pembatasan Sosial Berskala Besar Dalam Rangka Percepatan Penanganan Corona Virus Disease 2019 (COVID19), (Kemenkes RI, 2020) Permenkes 9 tahun 2020 tentang Pedoman PSBB dalam rangka Percepatan Penanganan COVID-19 adalah Pembatasan Sosial Berskala Besar,

(Peraturan Gubernur, 2020) Pemerintah Provinsi DKI Jakarta menerbitkan Peraturan Gubernur Nomor 33 Tahun 2020 tentang Pelaksanaan Pembatasan Sosial Berskala Besar (PSBB) dalam Penanganan COVID-19 di Provinsi DKI Jakarta, Pemerintah Provinsi DKI Jakarta memberlakukan Pembatasan Sosial Berskala Besar (PSBB) yang pertama tanggal 10 23 April 2020), yang kedua tanggal 24 April hingga 22 Mei 2020, yang ketiga tanggal 23 Mei hingga 4 Juni 2020, yang keempat tanggal 5 hingga 30 Juni 2020, Peraturan Menteri Perhubungan Nomor 25 tahun 2020 tentang Pengendalian Transportasi Selama Musim Mudik Copyright $\odot 2020$ Edisi Khusus No. 1 (Juli 2020), Halaman: 1 - 14 
Idul Fitri $1441 \mathrm{H}$ dalam rangka pencegahan penyebaran Covid 19, Kedua peraturan ini sangat mempengaruhi industri pariwisata seperti pengurangan pegawai, pemutusan hubungan kerja, pemotongan gaji dan insentif.

Indikator pandemik covid-19 menurut (Budimanta, 2020) adalah sebagai berikut: reproduction rate $(\mathrm{RT})$ dibawah 1 selama 14 hari; resiko inheren penularan covid-19 untuk setiap sector ekonomi; pengelolaan ekonomi dan resiko kesehatan; massive testing minimal 5 persen dari populasi; contact tracing dan equipment availability seperti Alat Pelindung Diri (APD), protokol kesehatan, promosi, hingga pengawasan.

\subsection{Pendapatan Tempat Wisata dan Hiburan}

Beberapa indikator pendapatan tempat wisata dan hiburan menurut (Badan Pendapatan Daerah DKI Jakarta, 2020) antara lain: jumlah penerimaan asli daerah dari sektor pajak daerah; persentase kesesuaian rencana dengan pencapaian target seluruh jenis pajak; jumlah Standard Operation Procedure (SOP) yang tersedia dalam proses pemungutan pajak daerah; jumlah jenis pajak yang mencapai target; jenis pajak yang termonitor dan terevaluasi secara optimal; jumlah peraturan perundang-undangan tentang perpajakan daerah yang disusun dan ditetapkan; jumlah peraturan pajak daerah yang tersosialisasikan; jumlah kasus perpajakan daerah yang terselesaikan (pendampingan dalam memberikan keterangan pelayanan pajak); dan jumlah Unit pelayanan pajak yang beroperasi sesuai standar layanan.

Menurut (Dinas Pariwisata DKI Jakarta, 2020) bahwa jenis obyek daya tarik wisata terdiri dari: wisata alam, wisata budaya, wisata buatan, taman hiburan dan rekreasi, kawasan pariwisata dan wisata tirta. Menurut (Wikipedia, 2020) lokawisata, tempat wisata atau obyek wisata adalah sebuah tempat rekreasi atau tempat berwisata.

Menurut (Gubernur DKI Jakarta, 2015) Peraturan Gubernur DKI Jakarta tentang pajak hiburan bahwa besaran pajak tempat wisata dan hiburan bervariasi antara $5-25 \%$. Beberapa tempat-tempat pariwisata menurut (Dinas Pariwisata DKI Jakarta, 2020) adalah Kawasan Monas, Kawasan Kota Tua, Ancol (kawasan pantai), Dunia Fantasi, Atlantis Water Adventures, Ocean Dream Samudra, Sea World Ancol, Allianz Ecopark, Taman Margasatwa Ragunan, Anjungan DKI di Taman Mini Indonesia Indah (TMII), PBB Setu Babakan, Planetarium Taman Ismail Marzuki, Rumah si Pitung, Taman Arkeologi Onrust, Museum Bahari, Museum Sejarah Jakarta, Museum Prasasti, Museum MH Thamrin, Museum Seni Rupa dan Keramik, Museum Tekstil, Museum Wayang, Museum Joang 45, Museum MACAN, Museum Mandiri, Museum Maritim Indonesia, Museum Nasional Indonesia, Museum Sumpah Pemuda, Museum Kebangkitan Nasional, Lab Tari dan Karawitan Condet, Kawasan Perkampungan Budaya Betawi, Taman Benyamin Suaeb, Pulau Cipir dan Pulau Kelor. Beberapa hiburan terdiri dari: Klub Malam; Diskotek; Pub; Karaoke keluarga; Karaoke eksekutif; Bar; Griya pijat; SPA; Bioskop; Tempat bowling; Tempat biliar; Mandi uap; Seluncur dan Arena ketangkasan manual/elektronik. 


\subsection{Kinerja Karyawan Pariwsiata}

Menurut (Dinas Pariwisata DKI Jakarta, 2020), Jenis-jenis karyawan di tempat wisata dan hiburan terdiri dari PNS, pegawai tetap, pegawai tidak tetap, pegawai kontrak dan pegawai sukarela atau pegawai tidak dibayar, pramuwisata. Para karyawan dapat melakukan pekerjaannya secara work from home and work from office selama masa pandemic covid-19 berlangsung sejak bulan Maret hingga Juni 2020. Menurut (Pradhan \& Jena, 2017), ada 3 indikator kinerja karyawan, yaitu: kinerja tugas atau task performance, kinerja adaptif atau adaptive performance and kinerja kontektual atau contextual performance (TAC).

\subsection{Kerangka Penelitian}

Pada Gambar 1 dijelaskan kerangka penelitian yang digunakan dalam penelitian ini.

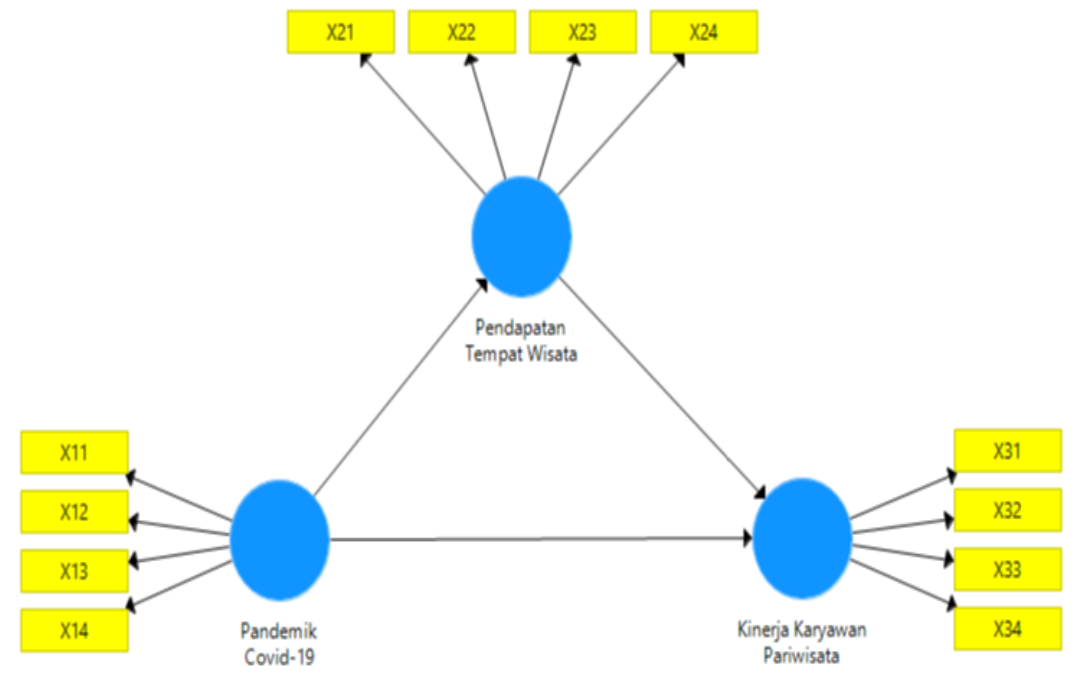

Sumber: Hasil Penelitian (2020)

\subsection{Hipotesis}

Gambar 1. Kerangka Penelitian

Berikut adalah hipotesis-hipotesis dalam penelitian ini:

H1 Ada pengaruh pandemik covid-19 terhadap pendapatan tempat wisata

H2 Ada pengaruh pandemik covid-19 terhadap kinerja karyawan pariwisata

H3 Ada pengaruh pendapatan tempat wisata terhadap kinerja karyawan pariwisata

\section{Metode Penelitian}

Populasi dalam penelitian ini adalah semua anggota karyawan hotel, perjalanan dan wisata di Jakarta, Indonesia dengan menggunakan purposive sampling. Penelitian ini memperoleh sampel sebanyak 98, Data primer terdiri dari wawancara dengan kuesioner, observasi lapangan dan dokumentasi, data sekunder diperoleh dari Provinsi, Kementerian Pariwisata dan Ekonomi Kreatif, Dinas Pariwisata dan Ekonomi Kreatif, Tur dan Perjalanan Jakarta, Asosiasi Hotel Jakarta dan Asosiasi Tujuan Wisata Jakarta dan asosiasi maskapai penerbangan. Metode Penelitian Kuantitatif dengan analisis komposit reliabilitas, cronbach's 
alpha, average variance extracted (AVE), uji t dan $\mathrm{P}$ value dengan menggunakan Partial Least Square (PLS) Structural Equation Modeling (SEM).

\section{Hasil dan Pembahasan}

Pada Tabel 1 menjelaskan tentang Data Pandemik Covid-19 di Jakarta dan Indonesia Tahun 2020.

Tabel 1. Data Pandemik Covid-19 di Jakarta dan Indonesia Tahun 2020

\begin{tabular}{crrrr}
\hline \multicolumn{1}{c}{ Bulan } & Lokasi & Terinfeksi & Meninggal & Sembuh \\
\hline Maret & Indonesia & 1.528 & 165 & 81 \\
& Jakarta & 747 & 83 & 48 \\
& Indonesia & 7.804 & 792 & 1.522 \\
April & Jakarta & 4.175 & 371 & 486 \\
& Indonesia & 26.473 & 1.613 & 7.308 \\
Mei & Jakarta & 7.383 & 521 & 2.246 \\
& Indonesia & 58.439 & 2.765 & 24.883 \\
Juni & Jakarta & 11.270 & 640 & 6.512
\end{tabular}

Source: (Minister of Health of the Republic of Indonesia, 2020)

Pada Tabel 2 menjelaskan tentang Kunjungan Wisatawan Mancanegara dan Nusantara di Jakarta.

Tabel 2. Kunjungan Wisatawan Mancanegara dan Nusantara di Jakarta

\begin{tabular}{crrr}
\hline Turis & \multicolumn{1}{c}{2018} & 2019 & \multicolumn{2}{c}{2020} \\
\hline Asing & & & 357,533 \\
& & & (January - Mei) \\
& $2,811,958$ & $2,940,000$ & $6,416,667$
\end{tabular}

Source: (Minister of Health of the Republic of Indonesia, 2020)

Pada Tabel 3 menjelaskan tentang Kontribusi Pajak Tempat Wisata dan Hiburan Terhadap Penerimaan Asli Daerah di Jakarta.

Tabel 3. Kontribusi Pajak Tempat Wisata dan Hiburan Terhadap Penerimaan Asli Daerah di Jakarta

\begin{tabular}{crrr}
\hline & 2018 & 2019 & 2020 \\
\hline Rencana & 850.000 .000 .000 & 860.000 .000 .000 & 1.100 .000 .000 .000 \\
\hline Realisasi & 834.004 .000 .000 & 860.000 .000 .000 & $\begin{array}{r}122.430 .000 .000 \\
\text { (January - Mei) }\end{array}$ \\
\hline Peneriman Asli Daerah & 61.235 .825 .000 .000 & 74.776 .745 .000 .000 & 11.150 .000 .000 .000 \\
\hline Persentase & $1,36 \%$ & $1,15 \%$ & $1,09 \%$ \\
\hline
\end{tabular}

Sumber: (Badan Pendapatan Daerah DKI Jakarta, 2020)

Pada Tabel 4 menjelaskan tentang Tempat Wisata dan Hiburan di Jakarta 13 Maret - 12 Juni 2020. 
Pengaruh Pandemik Covid-19 Terhadap Pendapatan Tempat Wisata dan Kinerja Karyawan Pariwisata di Jakarta

Tabel 4. Tempat Wisata dan Hiburan di Jakarta 13 Maret - 12 Juni 2020

\begin{tabular}{lll}
\hline Tempat Wisata dan Hiburan & 2020 & Persentase \\
\hline Total Tempat Wisata & 35 & $100 \%$ \\
\hline Tempat Wisata yang Ditutup & 28 & $80,00 \%$ \\
\hline Tempat Wisata yang Dibuka & 7 & $20,00 \%$ \\
\hline Total Tempat Hiburan & 2.525 & $100 \%$ \\
\hline Tempat Hiburan yang Ditutup & 1.400 & $55,45 \%$ \\
\hline Tempat Hiburan yang Dibuka & 1.125 & $44,55 \%$ \\
\hline
\end{tabular}

Sumber:(Dinas Pariwisata DKI Jakarta, 2020)

Pada Tabel 5 menjelaskan tentang Construct Reliability and Validity.

Tabel 5. Construct Reliability and Validity

\section{Construct Reliability and Validity}

\begin{tabular}{|c|c|c|c|c|c|c|c|}
\hline \multirow[t]{2}{*}{ Matrix } & 掉昔 Cronbach's Alpha & 掉章 rho_A & \multicolumn{2}{|c|}{ 㩰率 Composite Reliability } & \multicolumn{2}{|c|}{ 㩰革 Average Variance Extracted (... } & Copy to Clipboarc \\
\hline & & \multicolumn{2}{|c|}{ Cronbach's Alpha } & rho_A & Composite Reliability & \multicolumn{2}{|c|}{ Average Variance Extracted ... } \\
\hline \multicolumn{2}{|c|}{ Pandemik Covid-19 } & \multicolumn{2}{|c|}{0.777} & 0.780 & 0.857 & & 0.601 \\
\hline
\end{tabular}

Sumber: Hasil Pengolahan Data (2020)

Pada Gambar 2 menjelaskan tentang Composite Reliability.

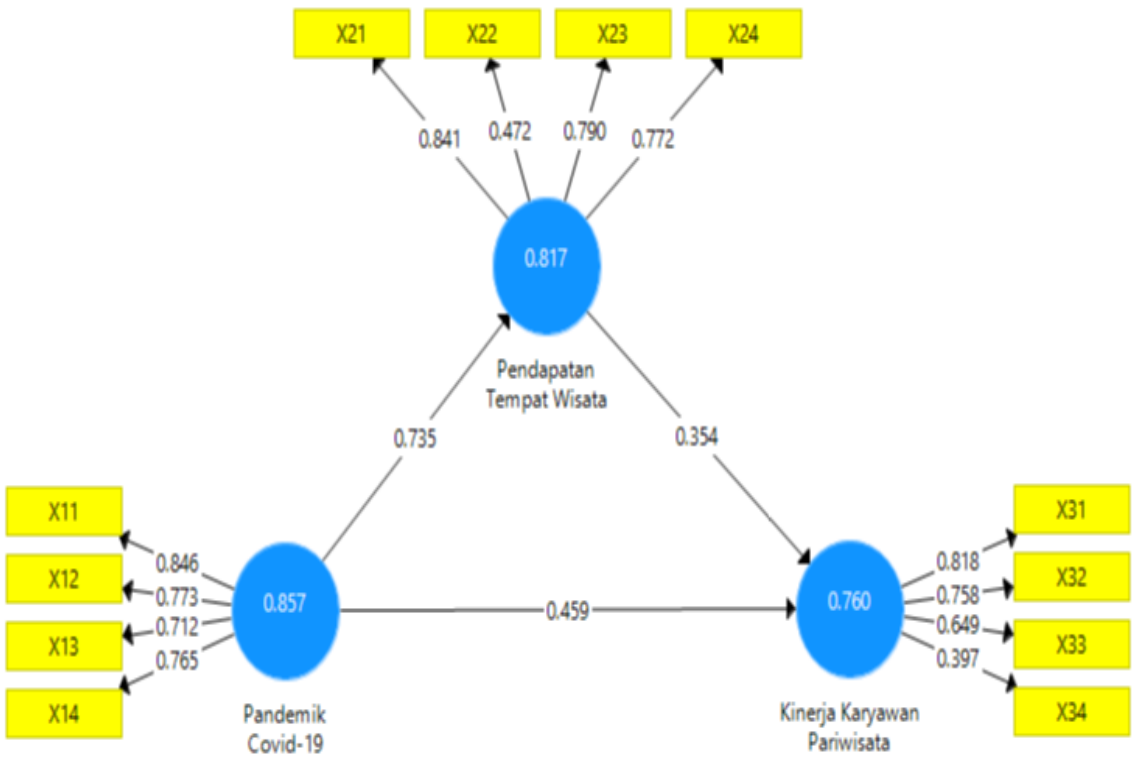

Sumber: Hasil Pengolahan Data (2020)

Gambar 2. Composite Reliability

Pada Gambar 3 menjelaskan tentang Cronbach's Alpha.

Copyright @ 2020 Edisi Khusus No. 1 (Juli 2020), Halaman: 1 - 14 


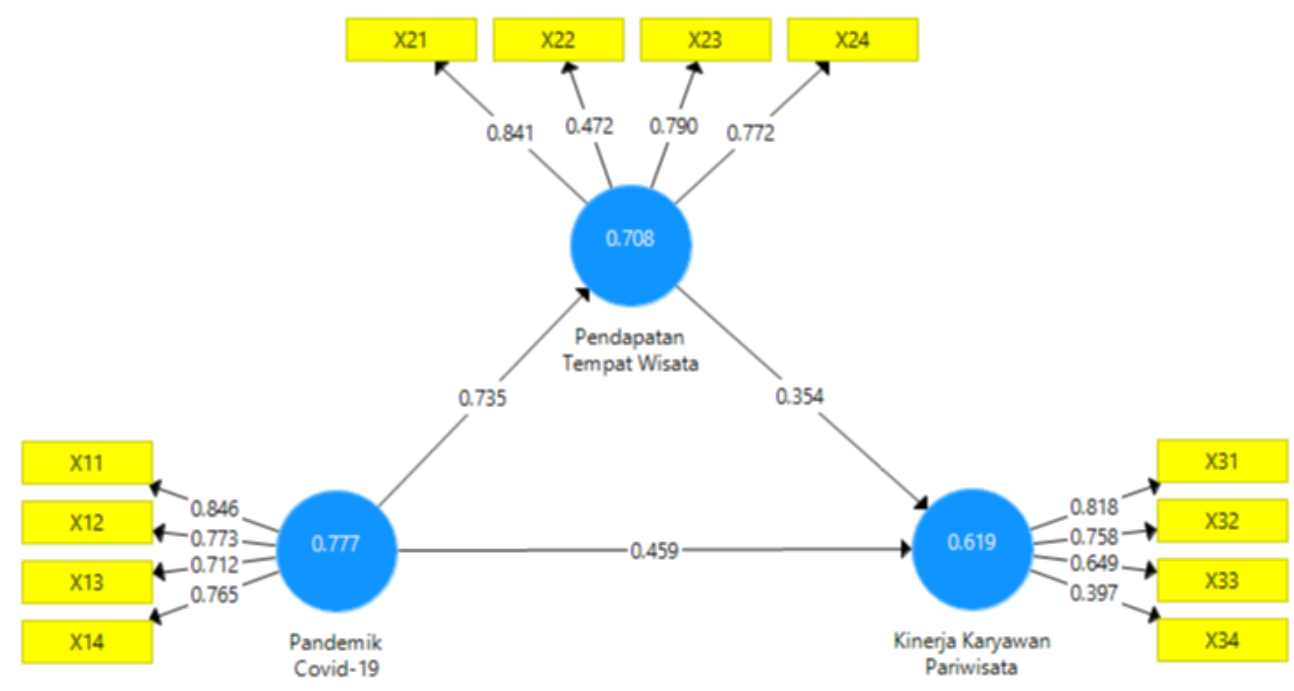

Sumber: Hasil Pengolahan Data (2020)

Gambar 3. Cronbach's Alpha

Pada Gambar 3 menjelaskan tentang Average Variance Extracted (AVE).

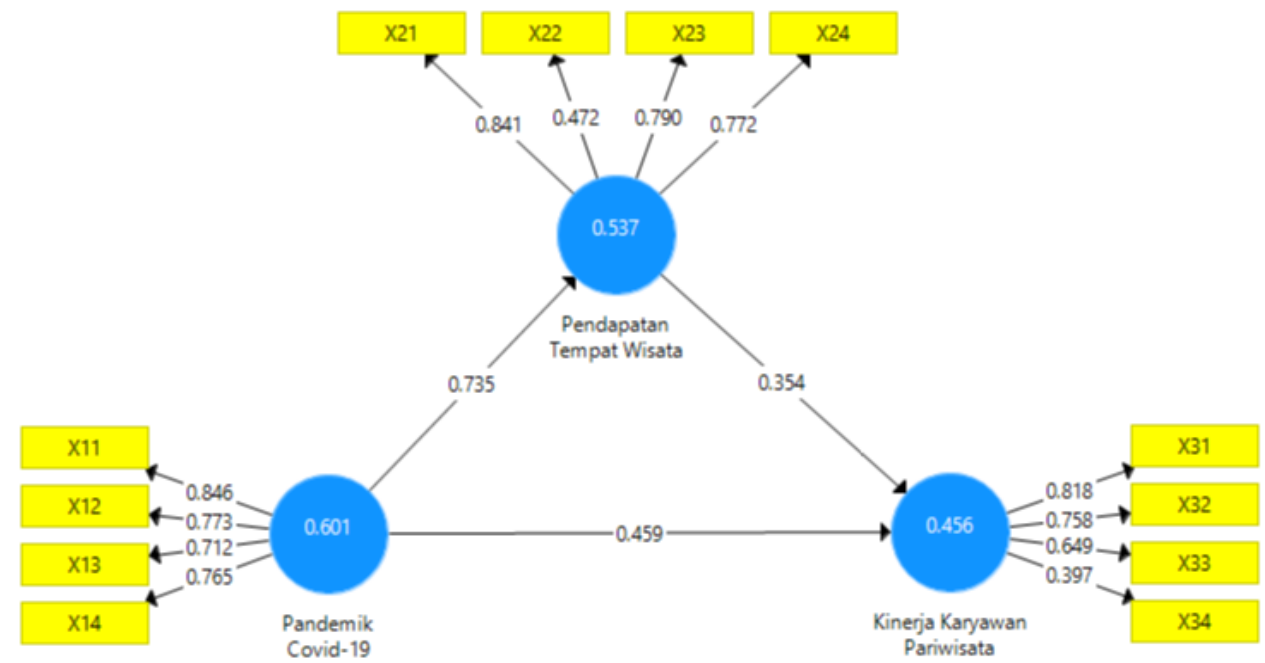

Sumber: Hasil Pengolahan Data (2020)

Gambar 4. Average Variance Extracted (AVE)

Berdasarkan Tabel 5, Gambar 3 dan 4 dengan menggunakan software Partial Least Square (PLS), Structural Equation Modeling (SEM) bahwa untuk menentukan validitas dan reliabilitas dapat digunakan dengan beberapa cara seperti: composite reliability, cronbach's alpha and average variance extracted (AVE). Nilai composite reliability untuk karyawan pariwisata, pandemik covid-19 dan pendapatan tempat wisata $\geq 0,70$ artinya nilai reliabilitas komposit untuk karyawan pariwisata, pandemik covid-19 dan pendapatan tempat wisata dapat diterima atau dapat dikatakan valid. Nilai cronbach's alpha untuk karyawan pariwisata, pandemik covid-19 dan pendapatan tempat wisata $\geq 0,60$, berarti nilai cronbach's alpha dapat diterima atau dapat dikatakan reliabel atau konsisten. Nilai AVE untuk pandemik covid-19 dan 
pendapatan tempat wisata $\geq 0,50$, artinya rata-rata variance yang diekstrak oleh program dapat diterima, sedangkan nilai AVE untuk karyawan pariwisata $0,456 \leq 0,50$, artinya rata-rata variance yang diekstrak oleh program tidak dapat diterima. Meskipun nilai AVE untuk karyawan wisata tidak dapat diterima dan nilai composite reliability serta cronbach's alpha dapat diterima, maka penelitian dapat dilanjutkan ke tahap selanjutnya.

Pada Tabel 6 menjelaskan tentang Uji t dan P hitung.

Tabel 6. Uji t dan $\mathrm{P}$ hitung

Path Coefficients

\begin{tabular}{|c|c|c|c|c|c|c|c|}
\hline \multirow[t]{2}{*}{ 囯 Mean, STDEV, T-Values, P-Va... } & \multirow[t]{2}{*}{ 圊 Confidence Intervals } & \multicolumn{2}{|c|}{ Confidence Intervals Bias $C$... } & Samples & Copy to Clipboard: & Excel Format & \multirow[b]{2}{*}{ lues } \\
\hline & & Original Sampl... & Sample Mean (... & Standard Devia... & T Statistics $(\mid \mathrm{O} / \mathrm{ST} . .$. & & \\
\hline \multicolumn{2}{|c|}{ Pandemik Covid-19 -> Kinerja Karyawan Pariwisata } & 0.459 & 0.444 & 0.132 & 3.473 & & 001 \\
\hline \multicolumn{2}{|c|}{ Pandemik Covid-19 -> Pendapatan Tempat Wisata } & 0.735 & 0.745 & 0.061 & 12.148 & & .000 \\
\hline \multicolumn{2}{|c|}{ Pendapatan Tempat Wisata -> Kinerja Karyawan Pariwisata } & 0.354 & 0.368 & 0.146 & 2.424 & & .016 \\
\hline
\end{tabular}

Sumber: Hasil Pengolahan Data (2020)

Pada Gambar 5 menjelaskan tentang Uji T.

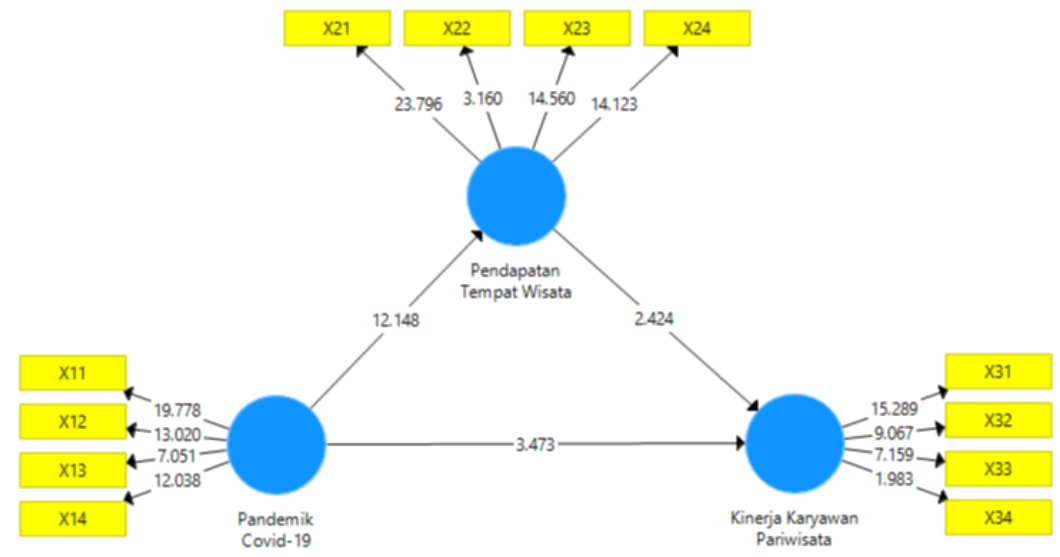

Sumber: Hasil Pengolahan Data (2020)

Gambar 5. Uji T

Pada Gambar 6 menjelaskan tentang P Value.

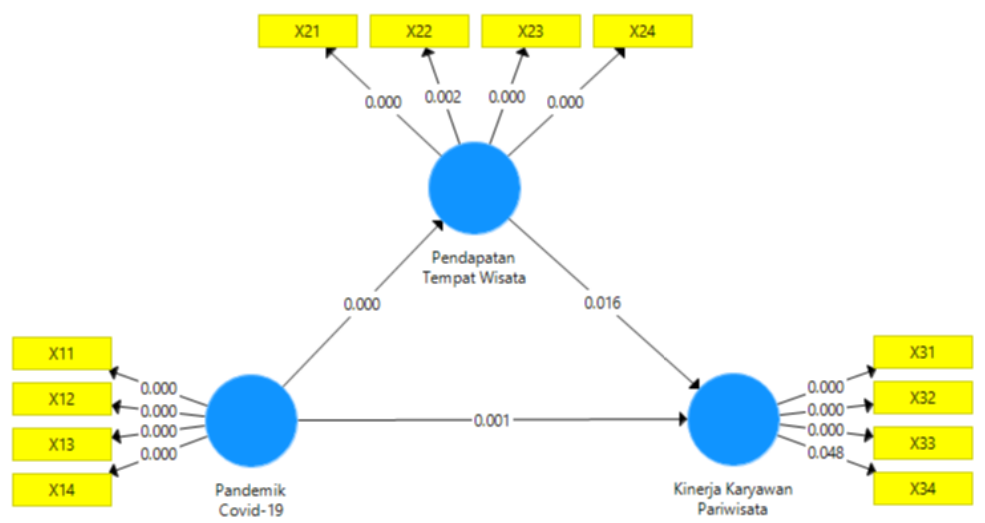

Sumber: Hasil Pengolahan Data (2020)

Gambar 6. P Value

Copyright @ 2020 Edisi Khusus No. 1 (Juli 2020), Halaman: 1 - 14 
Berdasarkan Tabel 6, Gambar 5 dan 6 uji t dan $P$ hitung menghasilkan hipotesis pertama bahwa $t$ hitung $(3,238) \geq t$ tabel $(1,990)$ dan nilai $P$ hitung $(0,001) \leq P$ tabel $(0,05)$, dapat diartikan ada pengaruh pandemik pandemik covid-19 terhadap karyawan pariwsata di Jakarta. Hipotesis kedua bahwa t hitung $(11,422) \geq t$ tabel $(1,990)$ dan nilai $P$ hitung $(0,000) \leq P$ tabel $(0,05)$, dapat diartikan ada pengaruh pandemik pandemik covid-19 terhadap pendapatan tempat wisata di Jakarta. Hipotesis ketiga bahwa diperoleh $t$ hitung $(2,343) \geq t$ tabel $(1,990)$ dan nilai $P$ hitung $(0,020) \leq P$ tabel $(0,05)$, dapat diartikan ada pengaruh pendapatan tempat wisata terhadap karyawan pariwsata di Jakarta.

Pada Tabel 7 dan Gambar 7 menjelaskan tentang R square.

Tabel 7. R square

\section{R Square}

\begin{tabular}{|c|c|c|c|}
\hline \multirow[t]{2}{*}{ Matrix } & 㩰萃 R Square & 模筆 R Square Adjusted & \multirow[b]{2}{*}{ R Square Adjusted } \\
\hline & & R Square & \\
\hline \multicolumn{2}{|c|}{ Karyawan Pariwisata_ } & 0.575 & 0.566 \\
\hline \multicolumn{2}{|c|}{ Tempat Wisata_ } & 0.541 & 0.536 \\
\hline
\end{tabular}

Sumber: Hasil Pengolahan Data (2020)

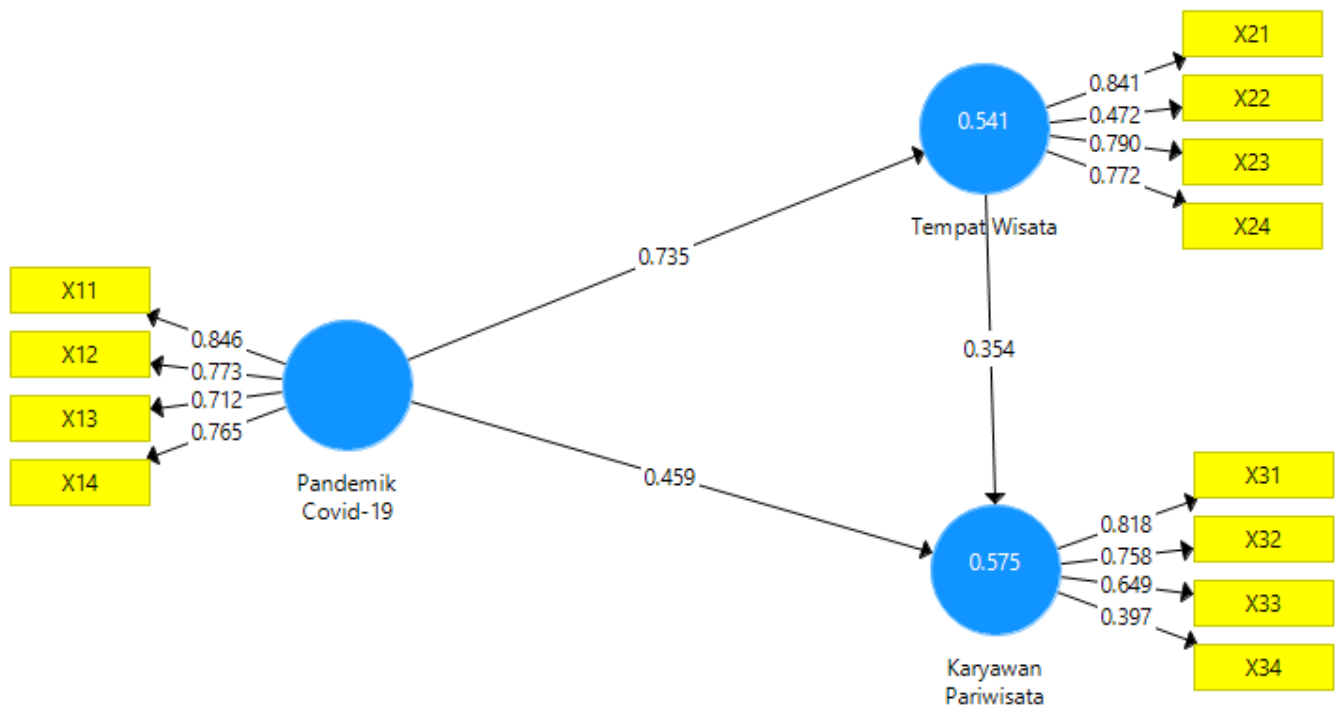

Sumber: Hasil Pengolahan Data (2020)

Gambar 7. R Square

Berdasarkan tabel 7 dan Gambar 7 R square dipeorleh Nilai R square untuk karyawan pariwsata sebesar 0,575 , artinya variabel laten karyawan pariwsiata berpengaruh $57,50 \%$ dan $42,50 \%$ dipengaruhi oleh variabel laten lainnya. Begitu pula dengan nilai $R$ square untuk 
pendapatan pendapatan tempat wisata sebesar 0,541 , artinya variabel laten pendapatan tempat wisata berpengaruh $54,10 \%$ dan $45,90 \%$ dipengaruhi oleh variabel laten lainnya.

\subsection{Pengaruh Pandemik Covid-19 terhadap Kinerja Karyawan Pariwisata di Jakarta}

Hipotesis pertama bahwa thitung $(3,238) \geq t$ tabel $(1,990)$ dan nilai $P$ hitung $(0,001) \leq P$ tabel $(0,05)$, dapat diartikan ada pengaruh pandemik pandemik covid-19 terhadap kinerja karyawan pariwsata di Jakarta. Semakin lama pendemik covid-19, maka semakin berpengaruh pada penurunan kinerja karyawan pariwisata. Indikator pandemik covid-19 yang paling dominan adalah resiko inheren penularan covid-19 dibandingkan dengan indicator lainnya seperti massive testing, equipment availability dan protokol kesehatan. Sedangkan indikator kinerja karyawan yang paling dominan adalah kinerja tugas atau task performance dengan cara work from home and work from office apabila dibandingkan dengan indikator lainnya seperti kinerja adaptif atau adaptive performance and kinerja kontektual atau contextual performance.

Penelitian ini mendukung penelitian sebelumnya yang dilakukan oleh (International Labour Organization, 2020) dengan judul Covid-19 and the World of Work: Impact and Policy Responses mengatakan bahwa covid-19 pandemic berpengaruh terhadap peningkatan pengangguran global antara 5,3 juta sampai dengan 24,7 juta pada tahun 2020. Penelitian ini mendukung penelitian yang dilakukan oleh (Minister of Health of the Republic of Indonesia, 2020) bahwa covid-19 pandemik sangat berpengaruh pada penurunan kinerja karyawan dibuktikan dengan peningkatan 747 kasus terinfeksi, 83 meninggal dunia dan 48 sembuh pada bulan Maret 2020 di Jakarta menjadi 11,270 terinfeksi, 640 meninggal dunia dan 6,512 sembuh pada bulan Juni 2020. Pandemik covid-19 berpengaruh pada penutupan sementara tempat wisata dan hiburan sebanyak 28 atau mengalami penurunan sebesar $80 \%$ dari total keseluruhan berjumlah 35 . Penutupan sementara tempat wisata dan hiburan berdampak negatif pada penurunan kinerja karyawan pariwisata seperti work from office menjadi work from home, pengurangan karyawan dan pemutusan hubungan kerja (PHK).

\subsection{Pengaruh Pandemik Pandemik Covid-19 terhadap Pendapatan Tempat Wisata di Jakarta}

Hipotesis kedua bahwa t hitung $(11,422) \geq t$ tabel $(1,990)$ dan nilai $P$ hitung $(0,000) \leq P$ tabel $(0,05)$, dapat diartikan ada pengaruh pandemik pandemik covid-19 terhadap pendapatan tempat wisata di Jakarta. Semakin lama pendemik covid-19, maka semakin berpengaruh pada penurunan pendapatan pendapatan tempat wisata. Indikator pandemik covid-19 yang paling dominan adalah resiko inheren penularan covid-19 dibandingkan dengan indicator lainnya seperti massive testing, equipment availability dan protokol kesehatan. Indikator pendapatan tempat wisata dan hiburan yang paling dominan adalah jumlah penerimaan asli daerah dari sektor pajak daerah apabila dibandingkan dengan indikator lainnya seperti persentase kesesuaian rencana dengan pencapaian target seluruh jenis pajak, jenis pajak yang termonitor dan terevaluasi secara optimal dan jumlah kasus perpajakan daerah yang terselesaikan.

Penelitian ini mendukung penelitian sebelumnya yang dilakukan oleh (Dinas Pariwisata DKI Jakarta, 2020) bahwa pandemik covid-19 berdampak pada penurunan jumlah tempat Copyright $\odot 2020$ Edisi Khusus No. 1 (Juli 2020), Halaman: 1 - 14 
wisata dan penurunan pendapatan pajak tempat wisata dan hiburan. Pandemik covid-19 berpengaruh pada penutupan sementara tempat wisata dan hiburan sebanyak 28 atau mengalami penurunan sebesar $80 \%$ dari total keseluruhan berjumlah 35 . Pandemik covid-19 juga berdampak pada tempat hiburan yang berjumlah 2.525 , tempat hiburan yang ditutup berjumlah 1.400 atau $55,45 \%$ dan tempat hiburan yang tetap dibuka berjumlah 1.125 atau 44,55\%. Realisasi pajak tempat wisata dan hiburan pada Januari hingga Mei 2020 diperkirakan mencapai 122.430 .000 .000 atau mengalami penurunan $34,17 \%$ apabila dibandingkan Januari hingga Mei 2019 berjumlah 358.333.000.000.

\subsection{Pengaruh Pendapatan Tempat Wisata terhadap Kinerja Karyawan Pariwsata di Jakarta.}

Hipotesis ketiga diperoleh $t$ hitung $(2,343) \geq t$ tabel $(1,990)$ dan nilai $P$ hitung $(0,020) \leq$ $P$ tabel $(0,05)$, dapat diartikan ada pengaruh pendapatan tempat wisata terhadap karyawan pariwsata di Jakarta. Semakin menurun pendapatan pendapatan tempat wisata, maka semakin berpengaruh pada penurunan kinerja karyawan pariwisata. Indikator pendapatan tempat wisata dan hiburan yang paling dominan adalah jumlah penerimaan asli daerah dari sektor pajak daerah dan indikator kinerja karyawan yang paling dominan adalah kinerja tugas atau task performance.

Penelitian ini juga mendukung data dari Perhimpunan Hotel dan Restoran Indonesia yang dilakukan oleh (Sukamdani, 2020) yang mengatakan pekerja sektor pariwisata sebanyak 90\% dirumahkan atau unpaid leave, di mana jumlah pekerja sektor pariwisata di Indonesia mencapai sekitar 13 juta orang. Penelitian ini mendukung penelitian sebelumnya yang dilakukan oleh (Dinas Pariwisata DKI Jakarta, 2020) bahwa penutupan sementara tempat wisata dan hiburan sebanyak 28 atau mengalami penurunan sebesar $80 \%$ dari total keseluruhan berjumlah 35. Penutupan jumlah tempat wisata selama bulan Maret hingga Juni 2020 berpengaruh pada penurunan pendapatan pajak wisata dan hiburan mempengaruhi kinerja karyawan pariwisata seperti pemotongan gaji dan insentif, tidak dibayar selama pandemic hingga pemutusan hubungan kerja atau PHK.

\section{Kesimpulan}

Pengaruh yang signifikan pandemik pandemik covid-19 terhadap kinerja karyawan pariwsata di Jakarta. Semakin lama pandemik covid-19, maka semakin berpengaruh pada penurunan kinerja karyawan pariwisata. Indikator pandemik covid-19 yang paling dominan adalah resiko inheren penularan covid-19 dibandingkan dengan indikator lainnya seperti massive testing, equipment availability dan protokol kesehatan. Sedangkan indikator kinerja karyawan yang paling dominan adalah kinerja tugas atau task performance dengan cara work from home and work from office apabila dibandingkan dengan indikator lainnya seperti kinerja adaptif atau adaptive performance and kinerja kontektual atau contextual performance. 
Penutupan sementara tempat wisata dan hiburan berdampak negatif pada penurunan kinerja karyawan pariwisata seperti pengurangan karyawan, pemotongan gaji dan insentif serta pemutusan hubungan kerja (PHK). Pengaruh pandemik covid-19 terhadap pendapatan tempat wisata di Jakarta. Semakin lama pendemik covid-19, maka semakin berpengaruh pada penurunan pendapatan pendapatan tempat wisata. Indikator pandemik covid-19 yang paling dominan adalah resiko inheren penularan covid-19 dibandingkan dengan indikator lainnya seperti massive testing, equipment availability dan protokol kesehatan. Indikator pendapatan tempat wisata dan hiburan yang paling dominan adalah jumlah penerimaan asli daerah dari sektor pajak daerah apabila dibandingkan dengan indikator lainnya seperti persentase kesesuaian rencana dengan pencapaian target seluruh jenis pajak, jenis pajak yang termonitor dan terevaluasi secara optimal dan jumlah kasus perpajakan daerah yang terselesaikan. Pengaruh pendapatan tempat wisata terhadap karyawan pariwsata di Jakarta. Pendapatan tempat wisata semakin menurun, maka berpengaruh pada penurunan kinerja karyawan pariwisata. Indikator pendapatan tempat wisata dan hiburan yang paling dominan adalah jumlah penerimaan asli daerah dari sektor pajak daerah dan indikator kinerja karyawan yang paling dominan adalah kinerja tugas atau task performance.

\section{Daftar Pustaka}

Badan Pendapatan Daerah DKI Jakarta. (2020). Indikator Pendapatan Asli Daerah. Website.

Budimanta, A. (2020). Adaptasi Ekonomi saat Pandemi Covid-19, Ini Strategi Pemerintah. Website.

Dinas Pariwisata DKI Jakarta. (2020). Surat edaran dengan nomor 155/SE/2020 tentang penutupan sementara kegiatan operasional industri pariwisata dalam upaya kewaspadaan terhadap penularan infeksi Corona virus desease (Covid-19). Website.

Gubernur DKI Jakarta. (2015). Peraturan Daerah Provinsi DKI Jakarta Nomor 3 Tahun 2015 tentang Pajak Hiburan. Website.

Handayanto, R. T., \& Herlawati, H. (2020). Efektifitas Pembatasan Sosial Berskala Besar (PSBB) di Kota Bekasi Dalam Mengatasi COVID-19 dengan Model Susceptible-InfectedRecovered (SIR). Jurnal Kajian IImiah, 20(2), 119-124. https://doi.org/10.31599/jki.v20i2.119

Harahap, S. W. (2020). Covid-19 di Indonesia Tanpa Puncak Pandemi? Website.

Herlawati, H. (2020). COVID-19 Spread Pattern Using Support Vector Regression. PIKSEL: Penelitian IImu Komputer Sistem Embedded and Logic, 8(1), 67-74. https://doi.org/10.33558/piksel.v8i1.2024

International Labour Organization. (2020). Covid -19 and the World of Work: Impact and Policy Responses. Website.

Kemenkes RI. (2020). Keputusan Presiden Republik Indonesia Nomor 9 Tahun 2020 Tentang Gugus Tugas Percepatan Penanganan Corona Virus Disease 2019 (Covid-19). Kementerian Kesehatan RI. 
Kepala Dinas Pariwisata dan Ekonomi Kreatif DKI Jakarta. (2020). Surat Edaran Dinas Pariwisata dan Ekonomi Kreatif Provinsi DKI Jakarta Nomor 155/se/2020 Tahun 2020. Website.

Keppres. (2020). Keputusan Presiden Republik Indonesia Nomor 9 Tahun 2020 Tentang Perubahan Atas Putusan Presiden Nomor 7 Tahun 2020 Tentang Gugus Tugas Percepatan Penanganan Corona Virus Disease 2019 (COVID-19) (Issue February 2019).

Minister of Health of the Republic of Indonesia. (2020). Dashboard Kasus COVID-19 di Indonesia. Website.

Pemerintah Republik Indonesia. (2020). Peraturan Pemerintah Republik Indonesia Nomor 21 Tahun 2020. Website.

Peraturan Gubernur. (2020). Peraturan Gubernur Provinsi Daerah Khusus Ibukota Jakarta. In Corona.Jakarta.Go.ld (Vol. 7, pp. 583-606).

Pradhan, R. K., \& Jena, L. K. (2017). Employee Performance at Workplace: Conceptual Model and Empirical Validation. Business Perspectives and Research, 5(1), 1-17. https://doi.org/10.1177/2278533716671630

Sukamdani, H. (2020). Covid-19 affected, 2,000 hotels and 8,000 restaurants closed. Website. Wikipedia. (2020). Lokawisata. Website.

World Health Organization. (2020). Archived: WHO Timeline - COVID-19. Website. 